\title{
Enzyme Enhanced Protein Recovery from Green Biomass Pulp
}

\author{
Gleb Dotsenko ${ }^{1} \cdot$ Lene Lange $^{1}$
}

Received: 4 March 2016/Accepted: 29 September 2016/Published online: 13 October 2016

(C) The Author(s) 2016. This article is published with open access at Springerlink.com

\begin{abstract}
Globally, animal feed protein is a key factor for production of meat for human consumption. Protein for animal feed is in many parts of the world not available in sufficient amounts; demand is met only through import of feed protein. Such protein deficit can be minimized through optimized use of local protein resources based on upgrade from e.g. green plant biomass. In present work we consider different strategies for protein recovery from white clover and ryegrass screw press pulps, using aqueous extraction, as well as carbohydrases and proteases enhanced extraction. Protein recovery in these studies was determined as a yield of solubilized protein with regard to the total protein in a screw press pulp. Aqueous extraction at $\mathrm{pH} 8.0$ resulted in approx. $40 \%$ protein recovery, while proteases application (Savinase 16.0L, Novozymes) enabled twice higher protein yield. Application of plant cell wall degrading enzymes (Cellic CTec2 and Cellic HTec2, Novozymes) did not provide detectable protein recovery, while consecutive proteases treatment resulted in approx. $95 \%$ protein yield. RuBisCO peptides were demonstrated by amino acid analysis to be the major component of white clover and ryegrass pulp proteolyzates, generated by Savinase $16.0 \mathrm{~L}$ protease.
\end{abstract}

Electronic supplementary material The online version of this article (doi:10.1007/s12649-016-9718-7) contains supplementary material, which is available to authorized users.

Lene Lange

lenl@kt.dtu.dk

1 Center for Bioprocess Engineering, Department of Chemical and Biochemical Engineering, Technical University of Denmark, 2800 Kgs. Lyngby, Denmark
Keywords Leaf protein - Screw press pulp · Carbohydrases · Proteases - White clover - Ryegrass

\section{Introduction}

Biomass conversion and biorefinery technologies, making value from biomass feed stocks, have so far focused primarily on upgrade of the lignocellulosic components of the biomass. In such processes the plant protein remained underexploited. Protein for animal feed is a key factor for production of meat for human consumption. In several areas around the world, such as e.g. Europe, protein for animal feed is imported at the same time as the local source of plant protein remains underexploited. In this work we investigate an optimized process for recovering of the plant protein from green plant biomass of both monocots (ryegrass) and dicots (white clover). The process is worked out in the perspective of being an integrated part of a value cascading of the green plant biomass, making use of upgraded proteins for monogastric animal feed, and use of the fibers plus residual proteins for cattle feed.

Efficient recovery of plant protein is a key point of green biomass value cascading. Until now protein extraction from leaves was focused primarily on mechanical disintegration, green juice separation and thermal precipitation of protein from green juice, while pulp protein remained underexploited. Upgraded processing of green biomass includes protein recovery not only from green juice, but also from the pulp. Resulting material (fibers + residual protein) is further used for C5 sugars recovery and high quality cattle feed production.

Nutritional value (bioaccessibility, amino acid profile and lack of antinutritional factors) of green plant protein concentrate is a crucial parameter for economic 
potentials of green plant biorefinery. Imported soybean protein in animal diet can be potentially replaced with leaf protein, only if leaf protein nutritional value at least matches the quality of soybean protein. This has still to be proven in commercial scale digestibility tests, however several studies have replaced soy meal to a different degree with green plant protein concentrates and reported promising results with no or little negative effect [1-3]. Maybe more importantly, these studies also show how process optimisation can increase quality of the protein concentrate by choosing the right up- and downstream processes [4].

The pivotal work of leaf protein extraction was started by Pirie $[5,6]$, he suggested mechanical disintegration of fresh green biomass, followed by squeezing of juice, and accomplished by protein separation from the liquid obtained. Proteins of plant leaf cell, as proteins of typical eukaryotic cell, are located in plasma membrane (integral and peripheral proteins) and cytoplasm. Cytoplasmic proteins constitute the major part of total protein pool in plant leaf cell. Cytoplasmic proteins are either directly dissolved in cytoplasm or included in organelles. In comparison with other organelles, chloroplasts accumulate the major part of leaf protein (up to $75 \%$ of total protein) [7]. Ribulose 1,5-bisphosphate carboxylase/oxygenase (RuBisCO, EC 4.1.1.39) is the most abundant enzyme of chloroplasts, catalyzing $\mathrm{CO}_{2}$ fixation in the first step of the Calvin cycle. RuBisCO is composed of eight large and eight small subunits with molecular weight approx. 55 and $13 \mathrm{kDa}$, respectively $[8,9]$. RuBisCO was reported as one of the most abundant proteins in the biosphere $[10,11]$, and thus it is of particular interest for green biomass biorefinery. After disintegration of fresh green leaves and juice squeezing cytoplasm dissolved proteins are harvested mainly in juice, while plasma membrane associated proteins and organelles proteins (mainly from chloroplasts) are separated between juice and solid press cake (pulp) in a proportion, depending on plant species and pressing techniques (on average, $50 \%$ of total protein remains in pulp fraction, bound with biomass cellulosic matrix).

Despite several physico-chemical methods of protein extraction from leaves were also suggested (alkaline extraction, [12]; aqueous ammonia extraction, [13]), mechanical disintegration of biomass, followed by juice squeezing, currently seems to be the most relevant method for protein separation from cellulosic matrix. Protein recovery, resulting from biomass common pressing and juice squeezing, is approx. 40-50\% [6, 14], while enhanced procedures with higher extent of cell wall disruption provide approx. $75 \%$ protein yield [15]. Even higher protein recovery was achieved for grasses $(84 \%)$ after biomass complete mechanical disintegration and tissues fractionating [16], but the latter process industrial application is still questionable because of the high level of energy consumption. Obviously, even after severe mechanical disintegration and liquid separation a certain part of the plant protein still remains in the pulp.

Since separated protein is of high economical interest in the green biorefinery concept, it will make sense to optimize the total yield of extracted plant protein. Thus it will be of particular interest to enhance overall protein yield from fresh green leaves by recovering protein from pulp in a low-cost and environmentally friendly process.

Enzymes are catalytic molecular machines, which application already benefited many industrial processes from economical and technological points of view [17], and it seems reasonable to investigate enzymes potential for protein recovery from green biomass pulp. At least two different strategies may be suggested for enzymatic protein recovery from leaf pulp-cell wall hydrolysis by carbohydrases [18], and protein hydrolysis by proteases [19].

The hypothesis for this study is that a significant proportion of the protein content in green leaves remains in the pulp fraction after screw pressing; and that such protein can be utilized efficiently as animal feed in two different ways. By remaining in the pulp fraction and used for dairy cows; or made bioaccessible also to non-ruminant animals by enzyme hydrolysis and used as feed ingredients for pigs, chickens, fish etc.

In this work we summarize our findings in protein recovery from ryegrass (Lolium perenne) and white clover (Trifolium repens) screw press pulps using aqueous extraction, as well as carbohydrases and proteases enhanced extraction.

\section{Materials and Methods}

\section{Green Biomass Pulps}

White clover and ryegrass pulps were kindly provided by Morten Ambye-Jensen (Aarhus University, Denmark). Pulp samples were obtained after fresh plants screw pressing and juice separation. DM content in white clover and ryegrass pulps was $32 \pm 1 \%$ and $33 \pm 1 \%$, respectively. Crude Kjeldahl protein content in white clover and ryegrass pulps was $16 \pm 1 \%$ and $10 \pm 1 \%$ with respect to DM. Pulp samples were stored at $-20{ }^{\circ} \mathrm{C}$.

\section{Enzymes and Reagents}

Cellic CTec2, Cellic HTec2, and Savinase 16.0L blends (liquid form) were produced by Novozymes (Denmark). All reagents used for buffers preparation and for Kjeldahl assay were provided by Sigma-Aldrich unless otherwise stated. 


\section{Protein Assays}

Four different methods for protein concentration determination in white clover and ryegrass samples were tested in this work (UV absorbance, Bradford, bicinchoninic acid, and Kjeldahl protein assays), while only UV absorbance and Kjeldahl protein assays were chosen for further research. RuBisCO extinction coefficient (Abs 1.7 for $1 \mathrm{~g} / \mathrm{L}$ concentration in $1 \mathrm{~cm}$ optical pathway) was used for protein concentration determination by UV absorbance protein assay $(280 \mathrm{~nm})$. Bradford protein assay was performed according to the original work [20]. Bicinchoninic acid protein assay was performed using Pierce BCA assay kit (Thermo Scientific), according to the manufacturer's instructions. BSA and bovine $\gamma$-globulins were used as standards for bicinchoninic acid and Bradford assays, respectively.

Kjeldahl assay was performed using BÜCHI speed digester K-425/K-436, scrubber B-414, and distillation unit $\mathrm{K}-350$, according to the manufacturer's instructions. $1 \mathrm{~L}$ of digesting reagent contained $134 \mathrm{~g} \mathrm{~K}_{2} \mathrm{SO}_{4}, 7.3 \mathrm{~g} \mathrm{CuSO}_{4}$, and $134 \mathrm{ml} \mathrm{H}_{2} \mathrm{SO}_{4} .1 \mathrm{~L}$ of ammonia trapping solution contained $500 \mathrm{~g} \mathrm{NaOH}$ and $25 \mathrm{~g} \mathrm{Na}_{2} \mathrm{~S}_{2} \mathrm{O}_{3} \cdot 5 \mathrm{H}_{2} \mathrm{O}$. Ammonia containing trapping solutions were titrated using $0.01 \mathrm{~N}$ $\mathrm{HCl}$ solution and mixed indicator solution (400 mg methyl red indicator, $200 \mathrm{mg}$ methyl blue indicator in $300 \mathrm{~mL}$ $95 \%$ ethanol). Total Kjeldahl nitrogen content was converted into total crude protein content by multiplying with the empirical coefficient of 6.25.

Amino acid analysis of pulp proteolyzates was performed at DTU. Data were corrected for the amount of added enzymes (enzymes blank) and presented as amino acid ratios, expressed in mole percent.

\section{Biomass Hydrolysis and Proteolysis}

Biomass hydrolysis (Cellic CTec2, Cellic HTec2) and proteolysis (Savinase 16.0L) reactions (reaction volume $20 \mathrm{~mL}$, biomass dry matter concentration $20 \mathrm{mg} / \mathrm{mL}$ ) were performed in $50 \mathrm{~mL}$ plastic tubes under continues shaking (200 rpm). Sodium azide at a final concentration of $3 \mathrm{mM}$ was used for prevention of microbial growth in all samples. Tween 80 at a final concentration of $0.5 \%$ wt was applied for testing of detergent effect on pulp protein recovery. UV absorbance protein assay was applied for protein recovery kinetics determination $(24,48,72 \mathrm{~h}$ points). $72 \mathrm{~h}$ point protein concentration was also measured by Kjeldahl assay. Biomass samples were incubated at $50{ }^{\circ} \mathrm{C}$ at $\mathrm{pH} 5.0$ (0.05 $\mathrm{M}$ sodium acetate/acetic acid buffer) and at $\mathrm{pH} 8.0$ (0.05 $\mathrm{M} \mathrm{Na} \mathrm{HPO}_{4} / \mathrm{NaH}_{2} \mathrm{PO}_{4}$ buffer) with either carbohydrases (Cellic CTec2 and Cellic HTec2) or proteases (Savinase 16.0L) for 24, 48, $72 \mathrm{~h}$ and then centrifuged $(13,000 \mathrm{rpm}, 10 \mathrm{~min})$. Supernatants thus obtained were used for protein determination. Biomass samples, incubated in water for $24,48,72 \mathrm{~h}$, were used as a substrate blanks in UV absorbance protein assay (for correction for non-protein UV-absorbing plant components). Enzyme blanks were performed using Savinase 16.0L (0.05 M $\mathrm{Na}_{2} \mathrm{HPO}_{4} / \mathrm{NaH}_{2} \mathrm{PO}_{4}$ buffer), Cellic CTec2, and Cellic HTec2 (0.05 M sodium acetate/acetic acid buffer) solutions. Biomass hydrolysis and proteolysis were performed in three replicates. Protein concentrations were corrected for the amount of added enzymes (enzymes blank) and presented as mean \pm standard deviation.

Protein yield in this work was determined as a ratio of solubilized protein to the total protein in a screw press pulp, expressed in percent. In case of enzymes addition (Cellic CTec2, Cellic HTec2, Savinase 16.0L) protein yield was corrected for the amount of added enzymes (enzymes blank).

\section{SDS-PAGE}

SDS-PAGE (4\% stacking gel and $12 \%$ separating gel) was performed following Mini-Protean Tetra Cell system instruction manual (Bio-Rad). Protein bands were revealed by staining with PageBlue staining solution (Thermo Scientific). Page ruler plus (Thermo Scientific) prestained $15-250 \mathrm{kDa}$ proteins were used as molecular weight markers.

\section{Statistical Analysis and Other Computations}

For analyzing statistical difference of two data sets Student's $t$ test with unequal variances was performed, using Microsoft Excel 2010 software. For analyzing statistical difference of three and more data sets single factor ANOVA was performed, using the same software. Statistical significance was estimated at $\mathrm{p}<0.05$.

Amino acid composition of white clover and ryegrass RuBisCOs was calculated by ProtParam (http://web.expasy. org/protparam/), using combined amino acid sequences of small and large subunits, retrieved from GenBank and UniProtKB/Swiss-Prot databases (white clover: UniProtKB/ Swiss-Prot P17673.1 + GenBank AHA37530.1; ryegrass: GenBank AIS19771.1 + CAO85984.1). Data were presented as amino acid ratios, expressed in mole percent.

For bioactive peptides identification, white clover and ryegrass RuBisCO sequences were analyzed by BIOPEP (http://www.uwm.edu.pl/biochemia/index.php/en/biopep).

\section{Results and Discussion}

\section{Protein Aqueous Extraction}

White clover and ryegrass pulps were incubated at $\mathrm{pH} 5.0$ and $\mathrm{pH} 8.0$ for $72 \mathrm{~h}$. Four different methods were used to 
quantify protein concentration in centrifuged solutions. All applied methods detected protein in $\mathrm{pH} 8.0$ incubated samples (Table 1), while no protein was found in any of the pH 5.0 incubated samples.

According to the data obtained, UV absorbance, Pierce bicinchoninic acid, and Bradford assays resulted in the statistically equal protein concentration for white clover pulp, while lower concentration was obtained by Kjeldahl assay. At the same time, UV absorbance, Bradford, and Kjeldahl assays resulted in the statistically equal protein concentration for ryegrass pulp, while higher protein concentration was obtained by Pierce bicinchoninic acid assay. Due to complexity of plant biomass composition, there are many interfering compounds, which may increase analytical signal in all these methods (reducing agents for bicinchoninic acid assay, aromatic compounds for UVabsorbance and Bradford assays), furthermore, bicinchoninic acid and Bradford assays are not compatible with detergents. Kjeldahl analysis results were taken as reference values for present research, because Kjeldahl analysis is compatible with detergents and much less affected by non-protein compounds, than other methods. Kjeldahl analysis is able to determine organic nitrogen in the form of proteins, oligopeptides, and free amino acids, which was an additional advantage for our study.

SDS-PAGE revealed a single low-molecular weight protein band $(\leq 15 \mathrm{kDa})$ for pulp samples, incubated at $\mathrm{pH}$ 8.0, while there were no bands for pulp samples, incubated at $\mathrm{pH} 5.0$ or in water (Fig. 1). Based on the data obtained, we suggest that protein extraction at $\mathrm{pH} 8.0$ may occur due to plant proteases action, and the observed protein band was formed by the front of running liquid, containing the resulting peptides. In living cells proteases are mainly localized in special organelles (lysosomes) and are not freely distributed in cytoplasm. After mechanical processing of green biomass lysosomes should be partially destroyed, which results in proteases liberation into cytoplasm. Majority of plant proteases demonstrate alkaline $\mathrm{pH}$ optima [21, 22], that's why protein recovery in aqueous extraction was observed at $\mathrm{pH}$ 8.0, rather than $\mathrm{pH}$ 5.0.

In present research UV absorbance protein assay was chosen for protein recovery kinetics investigation, because

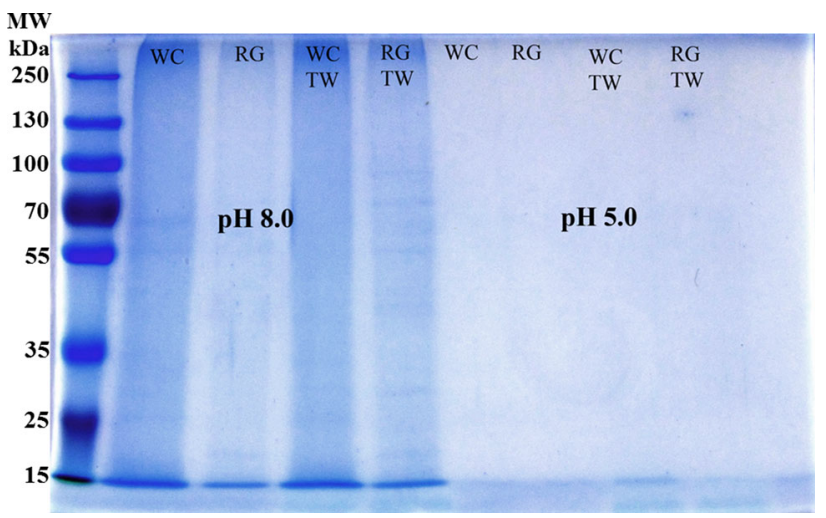

Fig. 1 SDS-PAGE of supernatants, obtained after $72 \mathrm{~h}$ of biomass pulps incubation at $\mathrm{pH} 8.0$ and $\mathrm{pH} 5.0,50{ }^{\circ} \mathrm{C}: M W$ molecular weight standards, $W C$ white clover, $R G$ ryegrass, $T W$ Tween $80,0.5 \%$

this assay can be easily carried out for large number of samples. Despite UV absorbance assay tends to increase real protein concentration, it is still relevant for evaluation of relative protein recovery progress. Protein concentration after $72 \mathrm{~h}$ incubation was measured by Kjeldahl assay and taken for protein recovery yield calculation. Protein recovery yields were calculated with respect to the pulp Kjeldahl crude protein content and expressed in percent. As can be seen from the data obtained (Table 2), 43 and $31 \%$ of pulp protein was recovered by aqueous extraction at $\mathrm{pH}$ 8.0 from white clover and ryegrass pulps, respectively. Interestingly, Sari et al. [23] found that approx. $7 \%$ of total protein can be extracted from not pretreated ryegrass at $\mathrm{pH}$ $10\left(25^{\circ} \mathrm{C}, 1\right.$ day). Higher protein yield, observed for ryegrass pulp in present work, should be due to mechanical pretreatment of biomass by screw pressing, as well as due to plant proteases action, activated by appropriate $\mathrm{pH}$.

Detergents are amphipathic molecules, which are able to destroy ordered structure of lipid bilayer membrane, facilitating membrane-associated proteins solubilization. Different detergents are widely applied in routine biochemistry practice for hydrophobic proteins solubilization (e.g. for membrane integral proteins purification [24]), thus we decided to test detergent effect on pulp protein recovery. Tween 80 detergent was chosen for all present experiments, because it is nontoxic and widely used in food
Table 1 Protein recovery from white clover and ryegrass screw press pulps by aqueous extraction

\begin{tabular}{lll}
\hline Protein assay method & \multicolumn{2}{l}{ Protein concentration in solution $(\mathrm{mg} / \mathrm{mL})$} \\
\cline { 2 - 3 } & White clover pulp & Ryegrass pulp \\
\hline UV absorbance assay $(280 \mathrm{~nm})$ & $1.9 \pm 0.2$ & $0.7 \pm 0.1$ \\
Pierce bicinchoninic acid assay & $2.0 \pm 0.2$ & $1.0 \pm 0.1$ \\
Bradford assay & $1.9 \pm 0.2$ & $0.7 \pm 0.1$ \\
Kjeldahl assay (crude protein) & $1.4 \pm 0.1$ & $0.6 \pm 0.1$ \\
\hline
\end{tabular}

Conditions $72 \mathrm{~h}, 50^{\circ} \mathrm{C}, \mathrm{pH} 8.0$, shaking $200 \mathrm{rpm}$, biomass dry matter concentration $20 \mathrm{mg} / \mathrm{mL}$ 
Table 2 Kinetics of protein recovery from white clover and ryegrass screw press pulps by aqueous extraction

\begin{tabular}{|c|c|c|c|c|c|}
\hline \multirow[t]{2}{*}{ Pulp; detergent } & \multicolumn{3}{|c|}{$\begin{array}{l}\text { Protein concentration in solution (based on UV absorbance) (mg/ } \\
\mathrm{mL} \text { ) }\end{array}$} & \multirow{2}{*}{$\begin{array}{l}\text { Kjeldahl protein }(\mathrm{mg} / \mathrm{mL}) \\
72 \mathrm{~h}\end{array}$} & \multirow{2}{*}{$\begin{array}{l}\text { Protein yield (\%) } \\
72 \mathrm{~h}\end{array}$} \\
\hline & $24 \mathrm{~h}$ & $48 \mathrm{~h}$ & $72 \mathrm{~h}$ & & \\
\hline White clover & $1.6 \pm 0.1$ & $1.8 \pm 0.2$ & $1.9 \pm 0.2$ & $1.4 \pm 0.1$ & 43 \\
\hline Ryegrass & $0.5 \pm 0.1$ & $0.7 \pm 0.1$ & $0.7 \pm 0.1$ & $0.6 \pm 0.1$ & 31 \\
\hline White clover; Tween 80 & $1.7 \pm 0.2$ & $1.9 \pm 0.2$ & $2.0 \pm 0.2$ & $1.7 \pm 0.1$ & 53 \\
\hline Ryegrass; Tween 80 & $0.7 \pm 0.1$ & $0.9 \pm 0.1$ & $0.8 \pm 0.1$ & $0.8 \pm 0.1$ & 40 \\
\hline
\end{tabular}

Conditions $50{ }^{\circ} \mathrm{C}$, pH 8.0, shaking $200 \mathrm{rpm}$, biomass dry matter concentration $20 \mathrm{mg} / \mathrm{mL}$

Statistically significant increase of protein yield, resulted from detergent addition, is indicated in bold

industry [25]. Tween 80 addition resulted in statistically significant increase of protein yield: 53 and $40 \%$ of protein was recovered from white clover and ryegrass pulps, respectively.

\section{Proteases Enhanced Protein Recovery}

Proteases are enzymes, which are involved in numerous metabolic pathways, concerning protein degradation in cells [26]. Sari et al. [19] demonstrated that commercial Genencor (Danisco) proteases (Protex 40XL, Protex P, Protex 5L, Protex 50FP, and Protex 26L) increase protein recovery from soybean, rapeseed, and microalgae. Thus next step of this work was to investigate proteases potential for protein recovery from white clover and ryegrass pulps. Commercial proteases blend Savinase 16.0L (Bacillus sp. proteases) was chosen for corresponding investigations, because it was recommended as the most suitable enzyme for releasing peptides from lentil proteins in comparison with three other commercially available proteases blends [27].

As can be seen from Table 3, Savinase 16.0L proteases resulted in approximately two times higher protein recovery, than was observed for aqueous extraction at $\mathrm{pH}$ 8.0. Interesting, Savinase 16.0L proteases provided similar protein yield from white clover and ryegrass pulps (79 and $76 \%$, respectively), while protein recovery at aqueous extraction was much higher for white clover pulp (43\%), than for ryegrass pulp (31\%). Such phenomenon could rise from different proteolytic activities in pulp samples, which in turn may rise from different extent of pulp mechanical disintegration. Ryegrass leaves demonstrate somewhat higher mechanical rigidity, than white clover leaves, and thus lysosomes disintegration and plant proteases liberation in ryegrass pulp may be lower, than those in white clover.

Tween 80 addition to Savinase 16.0L proteases did not result in statistically significant increase of protein yield, compared to corresponding experiments without detergent. SDS-PAGE of Savinase 16.0L treated samples did not reveal any plant protein bands, all presented bands corresponded to Savinase 16.0L proteins (data are not shown). The latter observation clearly indicated that Savinase 16.0L formed peptides molecular weight was lower than $15 \mathrm{kDa}$ ( $<15 \mathrm{kDa}$ peptides couldn't be detected by $12 \%$ SDSPAGE).

Minimal enzyme dosage, sufficient for required degree of substrate conversion, is an important economical and technological parameter of any enzyme catalyzed industrial process. Thus protein recovery dependence on Savinase 16.0L dosage was investigated (Table 4). As can be seen from Table 4, proteolysis yield was not increased by proteases dosages higher than $5 \mathrm{mg} / \mathrm{g}$. Moreover, $1.25 \mathrm{mg} / \mathrm{g}$ dosage resulted in statistically equal proteolysis yield, compared to higher dosages.

Table 3 Kinetics of protein recovery from white clover and ryegrass screw press pulps by Savinase 16.0L proteases

\begin{tabular}{|c|c|c|c|c|c|}
\hline \multirow[t]{2}{*}{ Pulp; detergent } & \multicolumn{3}{|c|}{$\begin{array}{l}\text { Protein concentration in solution } \\
\text { (based on UV absorbance) }(\mathrm{mg} / \mathrm{mL})\end{array}$} & \multirow{2}{*}{$\begin{array}{l}\text { Kjeldahl crude protein }(\mathrm{mg} / \mathrm{mL}) \\
72 \mathrm{~h}\end{array}$} & \multirow{2}{*}{$\begin{array}{l}\text { Protein yield }(\%) \\
72 \mathrm{~h}\end{array}$} \\
\hline & $24 \mathrm{~h}$ & $48 \mathrm{~h}$ & $72 \mathrm{~h}$ & & \\
\hline White clover & $2.8 \pm 0.2$ & $2.9 \pm 0.2$ & $2.8 \pm 0.2$ & $2.5 \pm 0.2$ & 79 \\
\hline Ryegrass & $1.5 \pm 0.1$ & $1.7 \pm 0.2$ & $1.7 \pm 0.2$ & $1.5 \pm 0.1$ & 76 \\
\hline White clover; Tween 80 & $2.7 \pm 0.2$ & $3.1 \pm 0.2$ & $3.1 \pm 0.2$ & $2.7 \pm 0.2$ & 84 \\
\hline Ryegrass; Tween 80 & $1.6 \pm 0.1$ & $1.9 \pm 0.2$ & $2.0 \pm 0.2$ & $1.6 \pm 0.1$ & 79 \\
\hline
\end{tabular}

Conditions $50{ }^{\circ} \mathrm{C}, \mathrm{pH} 8.0$, shaking $200 \mathrm{rpm}$, biomass dry matter concentration $20 \mathrm{mg} / \mathrm{mL}$. Savinase $16.0 \mathrm{~L}$ dosage was $5 \mathrm{mg}$ of protein per g of dry pulp 
Table 4 Dosage dependence of protein recovery from white clover and ryegrass screw press pulps by Savinase $16.0 \mathrm{~L}$ proteases

\begin{tabular}{|c|c|c|c|c|c|c|}
\hline \multirow[t]{2}{*}{ Pulp } & \multirow[t]{2}{*}{ Enzyme dosage (mg/g (DM)) } & \multicolumn{3}{|c|}{$\begin{array}{l}\text { Protein concentration in solution (based } \\
\text { on UV absorbance) }(\mathrm{mg} / \mathrm{mL})\end{array}$} & \multirow{2}{*}{$\begin{array}{l}\text { Kjeldahl crude protein }(\mathrm{mg} / \mathrm{mL}) \\
72 \mathrm{~h}\end{array}$} & \multirow{2}{*}{$\begin{array}{l}\text { Protein yield (\%) } \\
72 \mathrm{~h}\end{array}$} \\
\hline & & $24 \mathrm{~h}$ & $48 \mathrm{~h}$ & $72 \mathrm{~h}$ & & \\
\hline \multirow[t]{6}{*}{ White clover } & 20 & $2.8 \pm 0.2$ & $2.9 \pm 0.2$ & $2.9 \pm 0.2$ & $2.5 \pm 0.2$ & 79 \\
\hline & 10 & $2.8 \pm 0.2$ & $2.8 \pm 0.2$ & $2.9 \pm 0.2$ & $2.5 \pm 0.2$ & 79 \\
\hline & 5 & $2.7 \pm 0.2$ & $2.8 \pm 0.2$ & $2.8 \pm 0.2$ & $2.5 \pm 0.2$ & 79 \\
\hline & 2.5 & $2.7 \pm 0.2$ & $2.8 \pm 0.2$ & $2.9 \pm 0.2$ & $2.4 \pm 0.2$ & 75 \\
\hline & 1.25 & $2.6 \pm 0.2$ & $2.7 \pm 0.2$ & $2.7 \pm 0.2$ & $2.4 \pm 0.2$ & 75 \\
\hline & 0 & $1.6 \pm 0.1$ & $1.8 \pm 0.2$ & $1.9 \pm 0.2$ & $1.4 \pm 0.1$ & 43 \\
\hline \multirow[t]{6}{*}{ Ryegrass } & 20 & $1.5 \pm 0.2$ & $1.7 \pm 0.2$ & $1.6 \pm 0.2$ & $1.5 \pm 0.1$ & 76 \\
\hline & 10 & $1.5 \pm 0.2$ & $1.7 \pm 0.2$ & $1.7 \pm 0.2$ & $1.5 \pm 0.1$ & 76 \\
\hline & 5 & $1.5 \pm 0.2$ & $1.6 \pm 0.2$ & $1.7 \pm 0.2$ & $1.5 \pm 0.1$ & 76 \\
\hline & 2.5 & $1.3 \pm 0.1$ & $1.6 \pm 0.1$ & $1.6 \pm 0.1$ & $1.4 \pm 0.1$ & 70 \\
\hline & 1.25 & $1.4 \pm 0.1$ & $1.5 \pm 0.1$ & $1.6 \pm 0.1$ & $1.4 \pm 0.1$ & 70 \\
\hline & 0 & $0.5 \pm 0.1$ & $0.7 \pm 0.1$ & $0.7 \pm 0.1$ & $0.6 \pm 0.1$ & 31 \\
\hline
\end{tabular}

Conditions $50^{\circ} \mathrm{C}, \mathrm{pH} 8.0$, shaking $200 \mathrm{rpm}$, biomass dry matter concentration $20 \mathrm{mg} / \mathrm{mL}$

As already mentioned in the Introduction, $\mathrm{RuBisCO}$ is the most abundant enzyme of chloroplasts. Therefore, it was of particular interest to compare amino acid composition of pulp proteolyzate and RuBisCO. As can be seen from the data obtained (Fig. 2), amino acid composition of white clover and ryegrass pulp proteolyzates was rather similar to corresponding RuBisCOs composition. Low methionine and cysteine contents, obtained for pulps proteolyzate, may rise from experimental loss of these amino acids due to their oxidation during sample acid hydrolysis (6 M HCl). High similarity was found for approx. half of analyzed amino acids (Glu + Gln, Gly, His, Ile, Phe, Thr, Tyr, Val), while some differences were observed for others. In conclusion, the amino acid profiles of these proteolyzates suggest, that the protein in the pulp fractions is very closely related to (or include a major fraction of) the
RuBisCO-type protein (see Fig. 2), confirming that RuBisCO peptides form the major part of white clover and ryegrass pulp proteolyzates.

Bearing in mind that many peptides possess biological activity, white clover and ryegrass RuBisCO sequences were compared with database of bioactive peptides. Interestingly, many peptides with various biological activities can be potentially produced from RuBisCO by its digestion with proteases (list of bioactive peptides is provided in Supplementary). A number of RuBisCO peptides demonstrate beneficial healthy activities (e.g. immunostimulating, antioxidative, glucose uptake stimulating activities), which may be an additional advantage of pulp proteolyzate for feed application. Nevertheless, further studies are required for detailed characterization of biological effect of green biomass pulp proteolyzates.

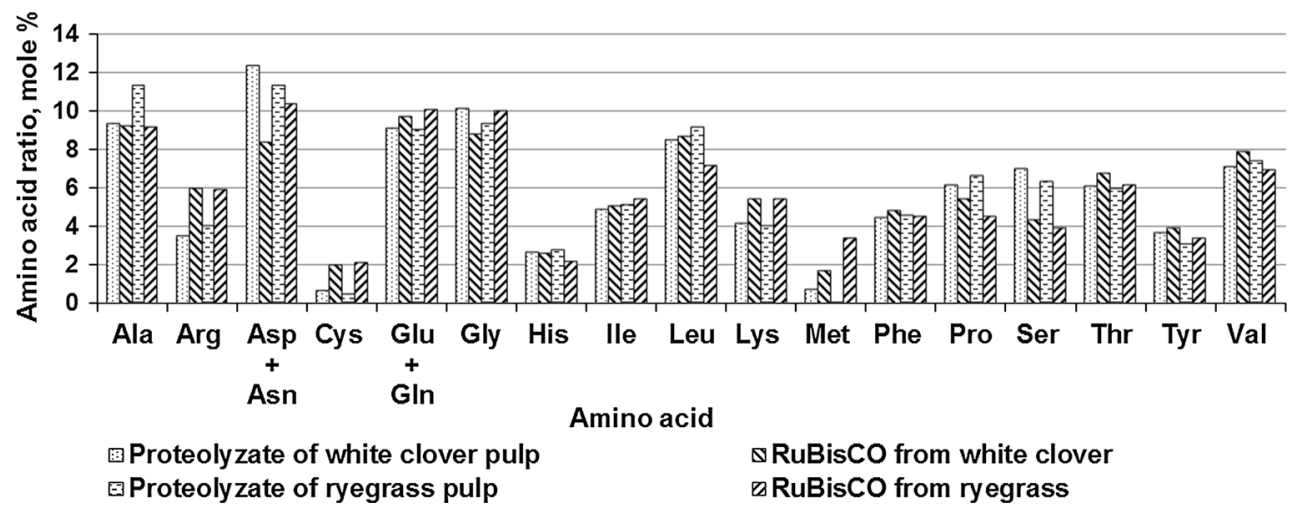

Fig. 2 Amino acid composition of white clover and ryegrass screw press pulp proteolyzates, compared to amino acid composition of plant RuBisCOs. (Pulps at the final dry matter concentration $20 \mathrm{mg} /$ $\mathrm{ml}$ were incubated at $50{ }^{\circ} \mathrm{C}, \mathrm{pH} 8.0,200 \mathrm{rpm}$ shaking for $72 \mathrm{~h}$ with Savinase $16.0 \mathrm{~L}$ at the final dosage $5 \mathrm{mg}$ of protein per $\mathrm{g}$ of dry pulp) 
Table 5 Kinetics of protein recovery from white clover and ryegrass screw press pulps by proteases after cellulosic cell walls hydrolysis by carbohydrases

\begin{tabular}{|c|c|c|c|c|c|}
\hline \multirow[t]{2}{*}{$\begin{array}{l}\text { Pulp; cell wall hydrolysis extent (modest or } \\
\text { exhaustive) }\end{array}$} & \multicolumn{3}{|c|}{$\begin{array}{l}\text { Protein concentration in solution } \\
\text { (based on UV absorbance) (mg/ } \\
\mathrm{mL} \text { ) }\end{array}$} & \multirow{2}{*}{$\begin{array}{l}\text { Kjeldahl crude protein }(\mathrm{mg} / \\
\mathrm{mL}) \\
72 \mathrm{~h}\end{array}$} & \multirow{2}{*}{$\begin{array}{l}\text { Protein yield } \\
(\%) \\
72 \mathrm{~h}\end{array}$} \\
\hline & $24 \mathrm{~h}$ & $48 \mathrm{~h}$ & $72 \mathrm{~h}$ & & \\
\hline White clover; modest & $2.9 \pm 0.2$ & $3.0 \pm 0.2$ & $3.0 \pm 0.2$ & $2.6 \pm 0.2$ & 81 \\
\hline Ryegrass; modest & $1.7 \pm 0.1$ & $1.9 \pm 0.2$ & $1.8 \pm 0.2$ & $1.6 \pm 0.1$ & 79 \\
\hline White clover; exhaustive & $2.9 \pm 0.2$ & $3.3 \pm 0.2$ & $3.4 \pm 0.2$ & $3.0 \pm 0.2$ & 94 \\
\hline Ryegrass; exhaustive & $1.9 \pm 0.2$ & $2.1 \pm 0.2$ & $2.1 \pm 0.2$ & $1.9 \pm 0.1$ & 95 \\
\hline
\end{tabular}

Conditions $50{ }^{\circ} \mathrm{C}, \mathrm{pH} 5.0$ for hydrolysis, $\mathrm{pH} 8.0$ for proteolysis, shaking $200 \mathrm{rpm}$, biomass dry matter concentration $20 \mathrm{mg} / \mathrm{mL}$. Cellic CTec2 and Cellic HTec2 dosages were 2.5 and $30 \mathrm{mg} / \mathrm{g}$ for modest and exhaustive hydrolysis $(24 \mathrm{~h}$ ); Savinase $16.0 \mathrm{~L} \mathrm{dosage} \mathrm{was} 5 \mathrm{mg} / \mathrm{g}$

Statistically significant increase of protein yield, comparing to unsupported proteases action, is indicated in bold

\section{Carbohydrases Enhanced Protein Recovery}

All cells are known to have a cell membrane (also referred to as plasma membrane) outside of them, which protects and organizes cells. Plant cells further have a cell wall, which provides additional protection and sufficient mechanical support. Plant cell wall is composed of cellulose, hemicelluloses, and lignin. It is cellulose that provides plant leaves essential elasticity in nature and at the same time complicates their mechanical disintegration in biorefinery [28]. Despite of certain mechanical processing of white clover and ryegrass leaves during screw pressing, partially broken cellulosic cell walls may still create steric hindrances for proteins diffusion outside the cells. To eliminate these steric hindrances, carbohydrases may be applied for plant cell walls hydrolysis. In this work Cellic CTec2 and Cellic HTec2 enzyme blends were chosen for pulp cell walls hydrolysis as a well-known source of efficient blends of cellulases and hemicellulases.

White clover and ryegrass pulp samples were hydrolyzed for $72 \mathrm{~h}\left(50{ }^{\circ} \mathrm{C}, \mathrm{pH} 5.0,20 \mathrm{mg} / \mathrm{ml}\right.$ biomass concentration, $30 \mathrm{mg} / \mathrm{g}$ enzymes dosage for Cellic CTec 2 and Cellic HTec2). Despite cellulosic cell wall hydrolysis into monomers was almost quantitative (based on glucose yield), no plant protein was detected in supernatants by Bradford and Kjeldahl protein assays after samples centrifugation. In order to exclude any error in protein determination, SDS-PAGE of hydrolyzates was performed. No plant protein bands were identified in the gel, all presented bands corresponded to Cellic CTec2 and Cellic HTec2 proteins (data are not shown). Tween 80 addition in $0.5 \%$ wt concentration did not affect plant protein recovery by carbohydrases.

Obtained results indicate that cellulosic cell wall steric hindrance is not the only one factor, limiting pulp protein recovery. Major part of pulp protein is located in chloroplasts, which are not affected by carbohydrases, because chloroplasts membrane includes $50-60 \%$ of protein and $40 \%$ of lipids [7]. We also suggest that some part of protein may aggregate into insoluble clusters. Chloroplasts membrane, as well as hypothetic protein clusters can be hydrolyzed by proteases. Thus it was of interest to investigate if proteolysis yield can be increased by preliminary cell walls hydrolysis. Cellic CTec2 and Cellic HTec2 mixture was applied for modest and exhaustive hydrolysis of white clover and ryegrass pulps. Samples thus obtained were treated by Savinase 16.0L proteases.

According to the data obtained (Table 5), cell walls modest hydrolysis did not result in statistically significant increase of following protein recovery by proteases, while exhaustive hydrolysis enhanced following protein recovery by proteases approximately 1.2 times in comparison with unsupported proteases action (Table 3). The latter observation indicates that cellulosic cell walls in screw pressed pulp and even in pulp, modestly hydrolyzed by carbohydrases, create a certain steric hindrances for proteases diffusion inside plant cells.

\section{Conclusions}

Currently, imported soybean protein is used in Europe as a major part of protein diet in animal production. At the same time, local high productive source of plant protein remains underexploited. Leaf protein is a valued product for animal feed production, which is potentially able to substitute high cost soybean protein. Substitution of soybean protein with leaf protein will minimize feed protein deficit and support economical sustainability. In present work we considered different strategies for protein recovery from white clover and ryegrass screw press pulps. Approximately $40 \%$ of total pulp protein was recovered by aqueous extraction at $\mathrm{pH} 8.0$, while approx. $80 \%$ of protein was recovered by 
proteases (Savinase 16.0L, Novozymes). Pulps hydrolysis by carbohydrases (Cellic CTec2 and Cellic HTec2, Novozymes) did not provide detectable protein yield, while it did increase following protein recovery by Savinase $16.0 \mathrm{~L}$ proteases up to approx. $95 \%$. RuBisCO peptides were demonstrated to be the major component of white clover and ryegrass pulp proteolyzates, generated by Savinase 16.0L proteases. Many RuBisCO peptides were identified as biologically active, using databases search. Therefore, further studies are required for detailed characterization of biological effect of green biomass pulp proteolyzates.

Acknowledgments This work is a part of and was supported by the Bio-Value Strategic Platform for Innovation and Research (www. biovalue.dk) which is co-funded by The Danish Council for Strategic Research and The Danish Council for Technology and Innovation, case no: 0603-00522B. We thank Morten Ambye-Jensen (Aarhus University, Denmark) for providing biomass screw press pulps and for making helpful suggestions and critical comments; appreciative acknowledge Anne Blicher (Department of Systems Biology, DTU) for the amino acid analysis; and appreciative acknowledge Professor Anne Meyer (Department of Chemical and Biochemical Engineering, DTU) for critically reading the manuscript.

Open Access This article is distributed under the terms of the Creative Commons Attribution 4.0 International License (http://crea tivecommons.org/licenses/by/4.0/), which permits unrestricted use, distribution, and reproduction in any medium, provided you give appropriate credit to the original author(s) and the source, provide a link to the Creative Commons license, and indicate if changes were made.

\section{References}

1. Cheeke, P.R., Kinzell, J.H., De Fremery, D., Kohler, G.O.: Freeze-dried and commercially prepared alfalfa protein concentrate evaluation with rats and swine. J. Anim. Sci. 44, 772-777 (1977)

2. Lu, C.D., Jorgensen, N.A., Straub, R.J., Koegel, R.G.: Quality of alfalfa protein concentrate with changes in processing conditions during coagulation. J. Dairy Sci. 64, 1561-1570 (1981)

3. Szymczyk, B., Gwiazda, S., Hanczakowski, P.: The nutritive value for rats and chicks of unextracted and defatted leaf protein concentrates from red clover and italian ryegrass. Anim. Feed Sci. Technol. 63, 297-303 (1996)

4. Bals, B.D., Dale, B.E., Balan, V.: Recovery of leaf protein for animal feed and high-value uses. In: Bergeron, C., Carrier, D.J., Ramaswamy, S. (eds.) Biorefinery Co-products: Phytochemicals, Primary Metabolites and Value-Added Biomass Processing, pp. 179-198. Wiley, Chichester (2012)

5. Pirie, N.W.: The direct use of leaf protein in human nutrition. Chem. Ind. 61, 45-48 (1942)

6. Pirie, N.W.: Leaf protein: Its Agronomy, Preparation, Quality and Use. Blackwell Scientific, Oxford (1971)

7. Godon, B., Vallery-Masson, D.: Protéines végétales. Technique et documentation. Lavoisier, Apria, Paris (1985)

8. Douillard, R., de Mathan, O.: Leaf protein for food use: potential of Rubisco. In: Hudson, B.J.F. (ed.) New and Developing Sources of Food Proteins, pp. 307-342. Chapman and Hall, London (1994)
9. Barbeau, W.E., Kinsella, J.E.: Ribulose bisphosphate carboxylase/oxygenase (Rubisco) from green leaves-potential as a food protein. Food. Rev. Int. 41, 93-127 (1988)

10. Ellis, R.J.: The most abundant protein in the world. Trends Biochem. Sci. 4, 241-244 (1979)

11. Raven, J.A.: Rubisco: still the most abundant protein of Earth? N. Phytol. 198, 1-3 (2013)

12. Zhang, C., Sanders, J.P.M., Bruins, M.E.: Critical parameters in cost-effective alkaline extraction for high protein yield from leaves. Biomass Bioenergy 67, 466-472 (2014)

13. Bals, B., Teachworth, L., Dale, B., Balan, V.: Extraction of proteins from switchgrass using aqueous ammonia within an integrated biorefinery. Appl. Biochem. Biotech. 143, 187-198 (2007)

14. Enochian, R.V., Kohler, G.O., Edwards, R.H., Kuzmicky, D.D., Vosloh, C.J.: Producing Pro-Xan (leaf protein concentrate) from alfalfa: economics of an emerging technology. Agricultural economic report No. 445, United States department of agriculture. http://naldc.nal.usda.gov/download/CAT80734699/PDF (1980). Accessed 01 Mar 2016

15. Sinclair, S., MacManus, R.: Protein extraction from pasture. Cost-benefit analysis: a feasibility study evaluation of both investment and economic implications. http://maxa.maf.govt.nz/ sff/about-projects/search/C08-001/cost-benifit-analysis.pdf (2009). Accessed 01 Mar 2016

16. Hulst, A.C., Ketelaars, J.J.M.H., Sanders, J.P.M.: Separating and recovering components from plants. Patent application WO2000 040788 A1 (2000)

17. Singhania, R.R., Patel, A.K., Thomas, L., Goswami, M., Giri, B.S., Pandey, A.: Industrial enzymes. In: Pandey, A., Höfer, R., Taherzadeh, M., Nampoothiri, K.M., Larroche, C. (eds.) Industrial biorefineries and white biotechnology, pp. 473-497. Elsevier, Amsterdam (2015)

18. Niemi, P., Martins, D., Buchert, J., Faulds, C.B.: Pre-hydrolysis with carbohydrases facilitates the release of protein from brewer's spent grain. Bioresour. Technol. 136, 529-534 (2013)

19. Sari, Y.W., Bruins, M.E., Sanders, J.P.M.: Enzyme assisted protein extraction from rapeseed, soybean, and microalgae meals. Ind. Crop. Prod. 43, 78-83 (2013)

20. Bradford, M.M.: Rapid and sensitive method for the quantitation of microgram quantities of protein utilizing the principle of protein-dye binding. Anal. Biochem. 72, 248-254 (1976)

21. Antão, C.M., Malcata, F.X.: Plant serine proteases: biochemical, physiological and molecular features. Plant Physiol. Biochem. 43, 637-650 (2005)

22. Greenberg, D.M., Winnick, T.: Plant proteases: II. pH-activity curves. J. Biol. Chem. 135, 775-780 (1940)

23. Sari, Y.W., Syafitri, U., Sanders, J.P.M., Bruins, M.E.: How biomass composition determines protein extractability. Ind. Crop. Prod. 70, 125-133 (2015)

24. Smith, S.M.: Strategies for the purification of membrane proteins. In: Walls, D., Loughran, S.T. (eds.) Protein chromatography: methods and protocols, pp. 485-496. Human press, New York (2011)

25. European parliament and council directive No 95/2/EC of 20 February 1995 on food additives other than colours and sweeteners. https://www.fsai.ie/uploadedFiles/95_2_EC.pdf. Accessed 01 Mar 2016

26. Rawlings, N.D., Salvesen, G.: Handbook of proteolytic enzymes, 3rd edn. Elsevier, Amsterdam (2013)

27. Garcia-Mora, P., Peñas, E., Frias, J., Martínez-Villaluenga, C.: Savinase, the most suitable enzyme for releasing peptides from lentil (Lens culinaris var. Castellana) protein concentrates with multifunctional properties. J. Agric. Food Chem. 62, 4166-4174 (2014)

28. Albersheim, P., Darvill, A., Roberts, K., Sederoff, R., Staehelin, A.: Plant Cell Walls, 3rd edn. Garland Science, New York (2011) 